\title{
Immuno flow cytometry in marine phytoplankton research*
}

\author{
L. PEPERZAK ${ }^{1}$, E.G. VRIELING ${ }^{2}$, B. SANDEE ${ }^{1}$ and T. RUTTEN ${ }^{1}$ \\ ${ }^{1}$ National Institute for Coastal and Marine Management / RIKZ, P.O. Box 8039, NL-4330 EA Middelburg, \\ The Netherlands. Fax (31) 118651 046; E-mail: L.Peperzak@rikz.rws.minvenw.nl \\ ${ }^{2}$ University of Groningen, Dept. of Marine Biology, P.O. Box 14, NL-9750 AA Haren, The Netherlands
}

\begin{abstract}
SUMMARY: The developments in the combination of flow cytometry and immunology as a tool to identify, count and examine marine phytoplankton cells are reviewed. The concepts of immunology and flow cytometry are described. A distinction is made between quantitative and qualitative immunofluorescence. Quantitative immunofluorescence, the identification and enumeration of phytoplankton cells, is the research area that has advanced rapidly in the past decade, and is reviewed extensively. Key steps of quantitative immunofluorescence, fixation and immunolabel intensity, are discussed in more detail. Qualitative immunofluorescence is a new, hardly explored but highly interesting development in which qualitative -physiological- variables related to e.g. nutrient limitation or primary production are measured in individual cells instead of phytoplankton populations as a whole. Several combinations of immunological probes, both for species identification and for physiological measurements, are proposed. A special case of qualitative immunofluorescence is the measurement of phytoplankton toxins in single cells from natural populations. It is anticipated that the future use of semiconductor nanocrystals or "quantum dots" as fluorophores will greatly enhance signal detection in flow cytometry, and hence in both quantitative and qualitative immunofluorescence applications.
\end{abstract}

Key words: flow cytometry, immunology, marine phytoplankton, fluorescence, European Optical Plankton Analyser (EurOPA), physiology, antibodies

\section{INTRODUCTION}

Immunology and flow cytometry are becoming powerful tools in the study of phytoplankton ecology. The application of immunology in phytoplankton research started thirty years ago when Bernhard et al. (1969) developed antibodies against the diatoms Leptocylindricus danicus and Phaeodactylum tricornutum. It was not, however, until the 1980's that immunological techniques for species identification were actually applied in marine research. The first species investigated were

\footnotetext{
*Received May 7, 1999. Accepted January 26, 2000.
}

prokaryotes (Dahl and Laake, 1982; Campbell et al., 1983), but some years later eukaryotic organisms followed (Hiroish et al., 1988; Shapiro et al., 1989). The swift development in the past decade of speciesspecific labelling with antibodies, especially for the identification of harmful algae, has been reviewed by Anderson (1995). A more general review on immunofluorescence in phytoplankton research was presented by Vrieling and Anderson (1996).

During the development of immunological techniques, the flow cytometer, a device that counts and measures cells in single file, became widely applied in aquatic research (Yentsch and Horan, 1989). The combination of flow cytometry and immunofluores- 
cence as a new tool to identify and count target cells in natural seston assemblages was outlined by Cucci and Robbins (1988). However, at that time this technique had not been applied in aquatic science yet.

In this paper the development of immunological techniques in marine eukaryotic phytoplankton research since Cucci and Robbins (1988) will be reviewed, focusing on the combination of immunology and flow cytometry. Firstly, the basics of immunochemical methods and flow cytometry will be explained. Then, the species-specific immunological probing, and quantitative immunofluorescence flow cytometry will be summarised. Finally, the possibilities of antibody application in physiological research will be described.

\section{IMMUNISATION, ANTIBODIES AND IMMUNOCHEMICAL METHODS}

Three important issues are distinguished for the immunolabelling of phytoplankton cells. Firstly, antibodies for the identification of specific molecules or cell types are essential, but they can only be obtained when the antigen is defined. Secondly, a selective reporter molecule, a fluorescent probe or fluorophore, should be selected for the adequate detection of antigens or cells in samples with multiple fluorescence signals. Finally, an efficient procedure is required for reproducible labelling at a most optimal intensity of the fluorescent signal of the reporter molecule.

\section{Immunisation}

The preparation of antibodies requires a proper definition of the antigen and the most useful antibodies are obtained using highly purified antigens. Good examples are antibodies that recognise specific cellular molecules of phytoplankton cells, which are of physiological or metabolic importance such as the carbon-fixing enzyme Rubisco (Orellana and Perry, 1992, 1995). Sometimes, however, the purification of the antigen is not possible or even not required as in the case of antibodies to cell surface components. In this case the whole cell, or cell wall fragments in a purified fraction, can be considered the antigen. In phytoplankton research whole cells or cell wall fragments, sometimes stabilised by aldehyde fixation, have often been used for small species such as Synechococcus and Aureococcus (Campbell et al., 1983; Anderson et al., 1989) as well as larger species such as dinoflagellates of the genera Alexandrium, Gymnodinium, and Prorocentrum, diatoms of the genus Pseudo-nitzschia, and raphidophytes of the genus Chattonella (Vrieling and Anderson, 1996 and references therein). Table 1 provides a detailed list of all eukaryotic marine phytoplankton species for which antibodies have been produced in the past decade.

After design of the antigen a host animal should be selected. Most commonly, rabbits are used but depending on the amount of antibodies needed, one can decide to use larger animals. For the establishment of "immortal" antibody-producing cell lines mice are immunised. Immunisation proceeds by repetitive injections of the antigen in the host animals. In general, antibodies are obtained within 6 months.

\section{Antibodies}

Antibodies are immunoglobulins that are secreted from activated lymphocytes when host organisms are exposed to foreign molecules or micro-organisms. Immunoglobulins are large molecules (150 to 950 $\mathrm{kDa}$ ) with a common feature of protein configurations; each containing identical short and large peptide chains that are known as light and heavy chains. Two heavy and light chains together form a typical Y-shaped molecule (Fig. 1). The molecule is divided into domains of which the regions where targets bind are highly variable. Adjacent variable domains of both the heavy and the light chain form the antigen binding sites (the Fab regions) per antibody molecule. The other domains, of which the tail end is also known as the Fc-region, are constant or conserved. The type of heavy chain distinguishes immunoglobulins in the classes $\operatorname{Ig} \mathrm{A}, \operatorname{IgG}, \operatorname{IgD}, \operatorname{IgE}$, and $\operatorname{IgM}$, of which $\operatorname{IgA}$ and $\operatorname{IgM}$ are di- and pentamers, respectively. In principle each lymphocyte produces antibodies that recognise one epitope of the antigen. The total serum of an immunised animal will contain many different antibodies that consequently is called a polyclonal antiserum (often referred to as polyclonal antibodies or PAbs). Uni-epitope specific or monoclonal antibodies (MAbs) can be obtained by fusing spleen cells of an immunised animal with myeloma cells, from which multiple hybridoma cell lines are established, each of which produces antibodies against one single epitope. A disadvantage of MAb's is that, in case of fixation, this single epitope may be destroyed so that a MAb will fail to bind, while a PAb would still recognise other epitopes. 
TABLE 1. - Marine eukaryotic phytoplankton species identification with immunological techniques. In cases where flow cytometry (fcm) was not applied (no), epifluorescence microscopy or magnetic beads were used.

\begin{tabular}{|c|c|c|c|c|c|}
\hline Class & species & $\begin{array}{l}\text { culture/field } \\
\text { application }\end{array}$ & $\begin{array}{l}\mathrm{PAb} / \\
\mathrm{MAb}^{\mathrm{c}}\end{array}$ & $\begin{array}{l}\text { fcm } \\
\text { applied }^{\mathrm{d}}\end{array}$ & reference \\
\hline \multirow[t]{4}{*}{ Bacillariophyceae } & Pseudo-nitzschia multiseries & culture/Wadden Sea & $\mathrm{PAb}^{\text {FITC }}$ & no & $\begin{array}{l}\text { Bates et al., 1993, Vrieling } \\
\text { et al., } 1996 \mathrm{~b}\end{array}$ \\
\hline & Pseudo-nitzschia multiseries & culture & $\mathrm{MAb}^{\mathrm{APC}}$ & EurOPA & $\begin{array}{l}\text { L. Peperzak \& B. Sandee, } \\
\text { unpublished }\end{array}$ \\
\hline & Pseudo-nitzschia pungens & culture/Wadden Sea & $\mathrm{PAb}^{\mathrm{FITC}}$ & no & $\begin{array}{l}\text { Bates et al., 1993, Vrieling et } \\
\text { al., 1996b }\end{array}$ \\
\hline & Thalassiosira oceanica & culture/Atlantic Ocean & $\mathrm{PAb}^{\mathrm{FITC}}$ & no & $\begin{array}{l}\text { Shapiro et al., 1989, Campbell } \\
\text { et al., } 1994\end{array}$ \\
\hline \multirow[t]{2}{*}{ Chlorophyceae } & Dunaliella tertiolecta & culture & $\mathrm{PAb}^{\mathrm{FITC}}$ & no & Shapiro et al., 1989 \\
\hline & B6125 (unidentified) & Atlantic Ocean & $\mathrm{PAB}^{\mathrm{FITC}}$ & no & Campbell et al., 1994 \\
\hline Cryptophyceae & Chroomonas salina & culture & $\mathrm{PAb}^{\mathrm{FITC}}$ & no & Shapiro et al., 1989 \\
\hline \multirow[t]{22}{*}{ Dinophyceae } & Alexandrium catenella & culture/Japanese coast & $\mathrm{MAb}^{\mathrm{FITC}}$ & EPICS ELITE $^{\circledR, b}$ & bako et al., 1993, Sako et al., 1996 \\
\hline & Alexandrium fundyense & culture/Gulf of Maine & MAb beads & no & $\begin{array}{l}\text { Sako et al., 1993, Aguilera et al., } \\
1996,1998\end{array}$ \\
\hline & Alexandrium lusitanicum & culture/Spanish coast & $\mathrm{PAb}^{\mathrm{FITC}}$ & no & Mendoza et al., 1995 \\
\hline & Alexandrium minutum & culture/Spanish coast & $\mathrm{PAb}^{\mathrm{FTTC}, \text { beads }}$ & EPICS $541^{\circledR}$ & $\begin{array}{l}\text { Mendoza } \text { et al., 1995, Costas } \\
\text { and Lopez-Rodas } 1996\end{array}$ \\
\hline & Alexandrium minutum & culture/New Zealand coast & $\mathrm{PAb}^{\mathrm{FITC}}$ & no & Chang et al., 1999 \\
\hline & Alexandrium tamarense & culture & $\mathrm{PAb}^{\mathrm{FITC}}$ & FACS STAR $^{\circledR}$ & Taylor and Lewis 1995 \\
\hline & Alexandrium tamarense & Japanese and Thai cultures ${ }^{g}$ & $\mathrm{MAb}^{\mathrm{FITC}}$ & & Adachi et al., 1993 \\
\hline & Alexandrium tamarense & culture/Japanese coast & $\mathrm{MAb}^{\mathrm{FTTC}}$ & EPICS ELITE $^{\circledR, b}$ & Sako et al., 1993, Sako et al., 1996 \\
\hline & Alexandrium tamarense & North Sea & $\mathrm{MAb}^{\mathrm{FITC}, \mathrm{b}}$ & no & Peperzak et al., 1998a \\
\hline & Gymnodinium catenatum & culture/Spanish coast & $\mathrm{PAb}^{\text {FITC }}$ & no & Mendoza et al., 1995 \\
\hline & G. mikimotoi ${ }^{a}$ & culture/central North Sea & $\mathrm{MAb}^{\mathrm{FTTC}}$ & OPA & Vrieling et al., 1994, 1995a, 1996a \\
\hline & G. mikimotoi ${ }^{a}$ & St. Lawrence Bay & $\mathrm{MAb}^{\mathrm{FITC}}$ & no & Blasco et al., 1996 \\
\hline & G. mikimotoi ${ }^{a}$ & North Sea & $\mathrm{MAb}^{\mathrm{FITC}, \mathrm{APC}}$ & no/EurOPA & $\begin{array}{l}\text { Peperzak et al., 1998a / } \\
\text { L. Peperzak \& B. Sandee, unpubl. }\end{array}$ \\
\hline & G. nagasakiense $e^{f}$ & culture & $\mathrm{MAb}^{\mathrm{FITC}}$ & no & Nagasaki et al., 1991 \\
\hline & Gymnodinium simplex & culture & PAb ${ }^{\text {FITC }}$ & OPA & Vrieling et al., 1993b \\
\hline & Gyrodinium sp. & culture/Spanish coast & $\mathrm{PAb}^{\mathrm{FITC}}$ & no & Mendoza et al., 1995 \\
\hline & Prorocentrum lima & culture & $\mathrm{PAb}^{\text {FITC }}$ & no & López-Rodas et al., 1998 \\
\hline & Prorocentrum micans & culture & $\mathrm{PAb}^{\mathrm{FITC}}$ & & López-Rodas et al., 1998 \\
\hline & Prorocentrum micans & culture & $\mathrm{PAb}^{\text {FITC }}$ & OPA & Vrieling et al., $1993 \mathrm{a}+\mathrm{b}$ \\
\hline & Prorocentrum minimum & culture & $\mathrm{PAb}^{\mathrm{FITC}}$ & no & López-Rodas et al., 1998 \\
\hline & Prorocentrum rostratum & culture & $\mathrm{PAb}^{\text {FITC }}$ & no & López-Rodas et al., 1998 \\
\hline & Prorocentrum triestinum & culture & $\mathrm{PAb}^{\mathrm{FITC}}$ & no & López-Rodas et al., 1998 \\
\hline \multirow[t]{3}{*}{ Pelagophyceae } & Aureococcus anophagefferens & s USA NE coast & $\mathrm{PAb}^{\text {FITC }}$ & no & Anderson et al., 1989, 1993 \\
\hline & Aureoumbra lagunensise & USA SE coast & $\mathrm{PAb}^{\text {FITC }}$ & no & López-Barreiro et al., 1998 \\
\hline & Pelagococcus subviridis & culture/Atlantic Ocean & $\mathrm{PAb}$ & no & $\begin{array}{l}\text { Shapiro et al., 1989, Campbell } \\
\text { et al., } 1994\end{array}$ \\
\hline \multirow[t]{2}{*}{ Prasinophyceae } & Micromonas pusilla & culture & $\mathrm{PAb}^{\mathrm{FITC}}$ & no & Shapiro et al., 1989 \\
\hline & Pycnococcus provasolii ( & Atlantic Ocean & DA FFITC & no & $\begin{array}{l}\text { Shapiro et al., 1989, Campbell } \\
\text { et al., } 1994\end{array}$ \\
\hline Prymnesiophyceae & Emiliania huxleyi & culture & $\mathrm{PAb}^{\mathrm{FITC}}$ & no & $\begin{array}{l}\text { Shapiro et al., 1989, Campbell } \\
\text { et al., } 1994\end{array}$ \\
\hline \multirow[t]{2}{*}{ Raphidophyceae } & $\begin{array}{l}\text { Emiliania huxleyi type A and B } \\
\text { Chattonella antiqua }\end{array}$ & $\begin{array}{l}\text { North Sea/Atlantic Ocean } \\
\text { culture/ North and Wadden Sea }\end{array}$ & $\begin{array}{l}\text { PAb } \\
\text { MAfTC }^{\text {FITC }}\end{array}$ & $\begin{array}{l}\text { no } \\
\text { no/no }\end{array}$ & $\begin{array}{l}\text { van Bleijswijk et al., } 1991 \\
\text { Hiroishi et al., 1988, Vrieling et }\end{array}$ \\
\hline & Chattonella marina & culture & $\mathrm{MAb}^{\mathrm{FITC}}$ & no & Hiroishi et al., 1988 \\
\hline
\end{tabular}

ammunologically identical to Gyrodinium aureolum and Gymnodinium nagasakiense

${ }^{\mathrm{b}}$ unsuccesfully applied in field samples

CPAb / MAb = Polyclonal / Monoclonal Antibody with fluorophore in superscript: FITC=conjugated using FluoresceinIsoThioCyanate; $\mathrm{APC}=$ AlloPhycoCyanin

${ }^{\mathrm{d}}$ EPICS $^{\circledR}=$ Coulter, FACS $^{\circledast}=$ Becton Dickinson, OPA $=$ Optical Plankton Analyser, EurOPA $=$ European Optical Plankton Analyser

'Texas Brown Tide organism

${ }^{\mathrm{f}} \mathrm{MAb} \mathrm{GN}-89$ did not label a Portuguese strain of $G$. cf. nagasakiense (Gyrodinium cf. aureolum)

${ }^{\text {g}}$ several strain-specific MAb's

Other differences between polyclonal and monoclonal antibodies are the financial costs and the amount of antibodies that can be obtained. The easiest way is the preparation of PAbs, since it is quite easy, quick (immunisation of about 3 months), and relatively cheap $(<\$ 500)$. The disadvantage is the relatively low amount of antibodies retrieved from a short- lived animal, which requires immunisation of new animals and repeated checking of antibody specificity and validity. The advantage of establishing antibody-producing cell lines or MAbs is that by careful screening clones can be selected that each produce antibodies recognising a highly specific epitope. Furthermore, these cell lines continuously produce anti- 


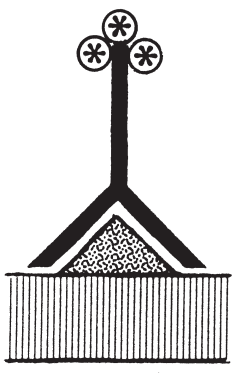

DIRECT

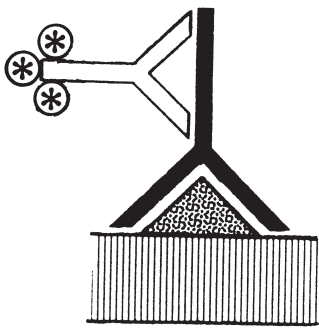

INDIRECT

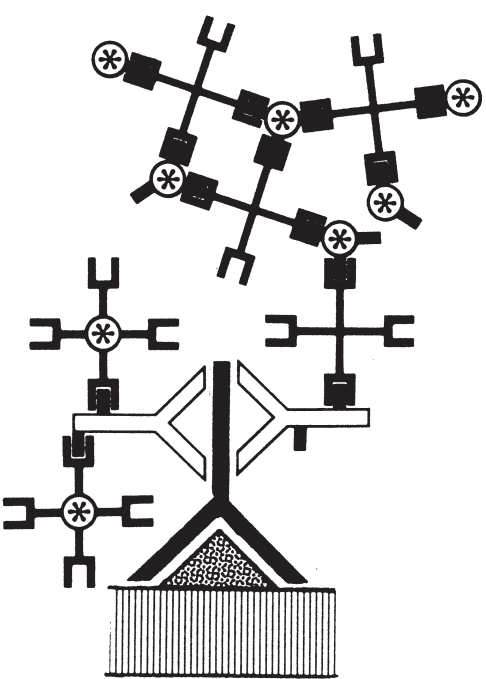

ENHANCED

FIG. 1. - Methods of immunofluorescence: direct, indirect and enhanced. Antibodies are Y-shaped: black = primary, white $=$ secondary antibody. Circles with stars are fluorescent labels or fluorophores. In the direct assay the fluorophore is bound to the primary antibody. In the indirect assay, the fluorophore is bound to the secondary antibody. In the enhanced assay, several molecules of biotin are linked to the secondary antibody. To the biotin fluorescent streptavidin is bound; this last step can be used to make fluorescent complexes. One streptavidin molecule can be linked directly with several fluorophores.

bodies in tissue cultures, and they can be stored in liquid nitrogen allowing production of new and identical batches whenever desired: the so-called "immortal" cell lines.

After obtaining antibodies, they should be tested for reactivity and specificity at various levels. The first step is determining the antigen binding capacity in a dilution series to determine the optimal concentration of the primary antibodies for use, or vice versa the required concentration of antigens at a given antibody concentration. The immune-response may vary by the pre-treatment of the samples.

\section{Immunochemical methods}

Complementary to the prepared antibodies are the desired reporter molecules for identification. For immuno flow cytometry only fluorescent probes are applicable. The antigens can be identified using either direct or indirect labelling, while the signal/noise-ratio of the indirect method can be improved by labelling enhancement procedures (Vrieling et al., 1993b). Direct immuno-labelling (Fig. 1) implies that the fluorescent molecule is directly attached to the antibody that recognises the antigen (the primary antibody). This method not only results in a lower background, but can be performed using fewer reagents and washing steps which are important considerations in quantification studies (Vrieling et al., 1996a, 1997). Direct immunofluorescence is easy for labelling the cell surface of phytoplankton cells. However, the labelling of intracellular antigens may not always be possible due to the charge or size of the antibodies. In most phytoplankton studies, the probe for identification has been linked to another antibody (a secondary antibody), that specifically binds to the applied primary antibody. If for example the primary antibody is raised in rabbits, the secondary should be an anti-rabbit antibody. These secondary antibodies can be purchased from various companies and multiple types are available with respect to the reactivity to the host of the primary antibodies, or the desired fluorescent reporter molecules. It is surprising, however, that from all available fluorescent molecules, the use of fluorescein isothyocyanate (FITC) dominates in immunofluorescence studies of phytoplankton (Table 1).

When the label intensity is not sufficient for the proper detection of a cell, the signal can be enhanced. In that case the primary or secondary antibody most often is covalently linked to several molecules of the vitamin biotin. By the use of fluorescently labelled (strept) avidin, compounds that have a very strong affinity for biotin, a complex formation of fluorescent molecules is realised (Fig. 1). 
These complexes result in an increase of the fluorescence intensity over common direct or indirect labelling procedures (Vrieling et al., 1993b).

Compared to direct immunofluorescence, the indirect methods for intracellular labelling are not importantly affected by permeability problems. Since multiple fluorescent molecules are coupled to the antigen the labelling intensity often increases. Furthermore, indirect assays are flexible with respect to the fluorescent reporter molecule used. Some disadvantages should also be considered. The number of wash and incubation steps increases in indirect assays, resulting in extra time and cell loss. Furthermore, additional background labelling as a result of non-specific binding of secondary antibodies may be introduced and more control measurements ("negative controls") should be performed.

\section{FLOW CYTOMETRY AND THE EUROPEAN OPTICAL PLANKTON ANALYSER}

Flow cytometry is applied for the determination of phytoplankton abundance for several reasons. Firstly, microscopic phytoplankton enumeration is labour intensive and is often not objective, cells smaller than about $4 \mu \mathrm{m}$ are not easy to discriminate and to enumerate. Secondly, the biomass of cell populations is difficult to assess accurately, because biomass is usually calculated by multiplication of the cell number and an overall estimate of the species cell volume. Thirdly, the amount of microscopic data obtained, e.g. in monitoring programmes is large and detailed and before these data can be interpreted, they usually are clustered into the main taxonomic groups (e.g. diatoms, flagellates). In contrast, flow cytometry allows the rapid enumeration of (small) cells, size measurements of large numbers of cells, and the combination of size with autofluorescent properties of individually detected cells can be used in cluster analyses.

Most oceanographic applications like the counting of small sized oceanic phytoplankton allow the use of standard commercial flow cytometers. However, coastal and inland species are not only highly heterogeneous in taxonomic composition, size, concentration, and morphology, but many also form colonies. Therefore, an optical plankton analyser (OPA; Peeters et al., 1989; Dubelaar et al., 1989) and later a more compact version, the European optical plankton analyser (EurOPA; Jonker et al., 1995) was designed and built.
The principle of flow cytometry, and the EurOPA in particular, is shortly described. A suspension of particles or (un)treated phytoplankton cells is sampled and is brought in a sheath flow resulting in a hydrodynamically focused sample stream (Fig. 2). The particles in this stream are transferred as a sin-

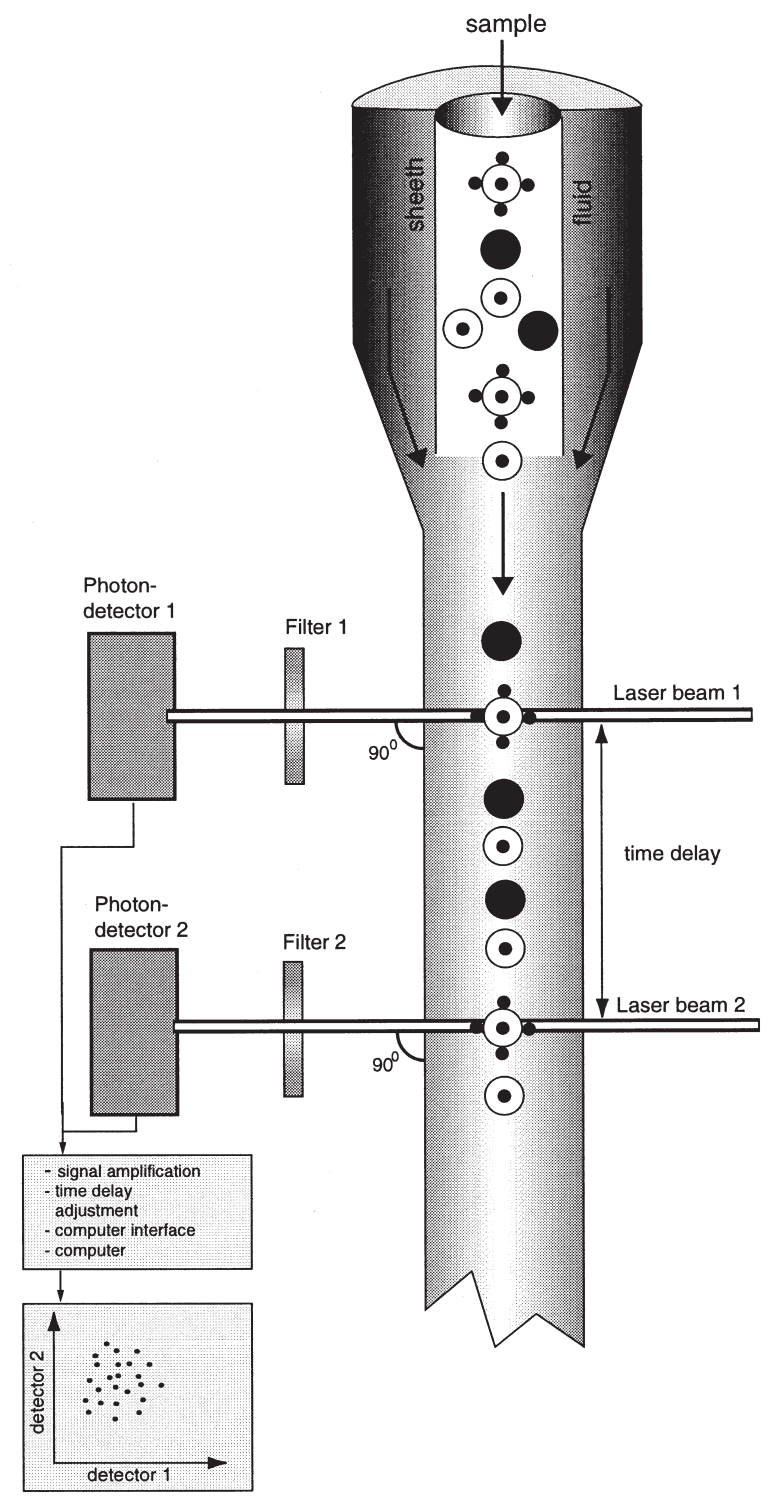

FIG. 2. - Schematic drawing of a dual beam flow cytometer. The sample, containing 3 different kinds of particles $(1$. black $=$ non-fluorescent, 2 . white + nucleus $=$ not species-specifically labelled but with a stained nucleus, 3 . white + nucleus +4 fluorophores) is pumped into the particle-free sheath-fluid. The sample stream is contained in the core ("hydrodynamic focusing"). The particles pass 2 laser beams in single file. Under a $90^{\circ}$ angle the fluorescent light is detected by "photondetectors", e.g. photomultipliers after the scattered laser light has been filtered. Unfiltered $90^{\circ}$ scattered laser light is called perpendicular light scatter (PLS) and is a measure of particle morphology and structure. Forward scattered laser light (FLS) is a measure of particle size. In the case of measuring the nuclear DNA concentration of G. mikimotoi cells (see Fig. 3), laser $1: \lambda=529 \mathrm{~nm}$, laser $2: \lambda=633 \mathrm{~nm}$, filters 1 and $2: \lambda>670 \mathrm{~nm}$. The signals from the photondetectors are processed with electronic hardware and a computer to produce so-called dot-plots. 
TABLE 2. - Excitation (EX) and emission (EM) wavelengths of the Optical Plankton Analyser (OPA), the European OPA (EurOPA) and commercially available flow cytometers, as listed in Table 1. PLS $=$ Perpendicular Light Scatter, FLS $=$ Forward Light Scatter, F $=$ Fluorescence, $\mathrm{B}=$ Blue, $\mathrm{G}=$ Green, $\mathrm{R}=$ Red. In dual beam flow cytometers such as the OPA and EurOPA a particle can be investigated with 2 lasers, e.g. green and red (see Fig. 2).

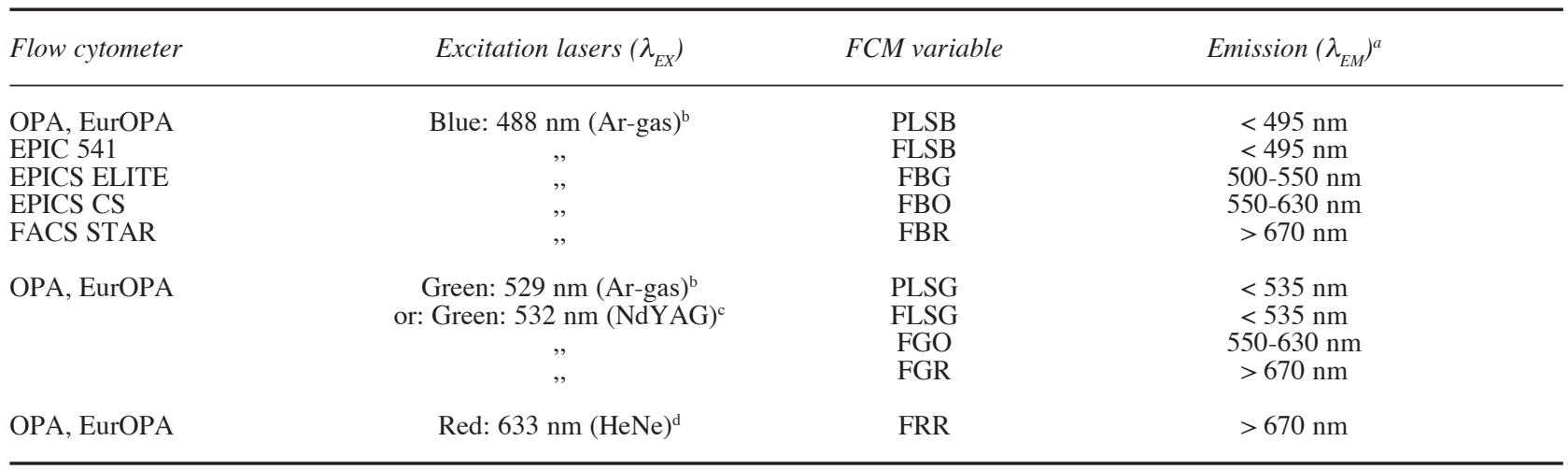

${ }^{\mathrm{a}}$ Eur(OPA) emission wavelengths

${ }^{\mathrm{b}}$ Argon, gas laser

'Neodynium Yttrium Aluminium Garnet, solid state laser

${ }^{\mathrm{d}}$ Helium Neon, gas laser

gle particle file with a constant velocity to one or two focused laser beams. A list of commonly used lasers is provided in Table 2.

Laser light is scattered when a particle crosses the laser beam. Forward scattered light (FLS) under very narrow forward angles correlates with particle size and shape according to Mie's derived Fraunhofer theory for small particles in the range of 2-20 $\mu \mathrm{m}$ (Cunningham and Buonaccorsi, 1992). Perpendicular light scatter (PLS) represents particle morphology and structure (Dubelaar et al., 1987; Ackelson et al., 1988). Laser light that irradiates chlorophyll containing phytoplankton is absorbed by the antenna pigments, and the excitation energy is transferred to the reaction centres of their two photosystems, that emit fluorescence (Krause and Weis, 1991). An additional process is the emission of fluorescence by accessory pigments (Yentsch and Yentsch, 1979; Yentsch and Phinney, 1988; Hof straat et al., 1991). Fluorescence emission excited by a green or blue laser is measured in perpendicular direction in the red region (FGR ( $\mathrm{G}=$ Green laser) or FBR (B=Blue laser): chlorophyll $a$ ) and in the orange bandwidth (FGO or FBO: phycoerythrines, phycocyanins). In the EurOPA the fluorescence emission of autotrophic phytoplankton cells excited by the second, red laser is measured (perpendicularly) in the red region (FRR, chlorophyll-b, phycocyanins). Typical excitation and emission wavelengths in flow cytometry are listed in Table 2.

The laser beam passage time, or the time of flight of a particle (TOF), corresponds with the particle length and is measured in the longitudinal direction, ranging from 1-1000 $\mu \mathrm{m}$ by the EurOPA. Commercial flow cytometers can only measure cells up to 50 $\mu \mathrm{m}$. The size of the scatter and fluorescence signals are integrated, and the measurements are stored in a data list ranging from $1-10^{8}$ arbitrary units.

Unfortunately, due to small differences in size and in pigment composition between many phytoplankton species, the flow cytometric discrimination in multi-species field samples is, unlike microscopy, still difficult (Hofstraat et al., 1994). In order to identify one species of interest in such samples, e.g. a harmful algal species, a program was started to produce species-specific antibodies. The antibodies

TABLE 3. - Excitation and emission wavelengths in nanometers of the fluorophores mentioned in the text, and of phytoplankton autofluorescence. Data from Shapiro 1985 and Vrieling and Anderson (1996).

\begin{tabular}{|c|c|c|c|c|c|}
\hline fluorophore & abbreviation & Excitation range & Excitation maximum & Emission range & Emission maximum \\
\hline Chlorophyll-a & Chla & $340-630$ & 440 & $650-750$ & 670 \\
\hline Calcofluor white & Calcofluor & $340-360$ & - & $400-440$ & - \\
\hline autofluorescent cell wall & - & $\begin{array}{c}- \\
4\end{array}$ & 460 & $\begin{array}{ll}- \\
-10\end{array}$ & 535 \\
\hline FluoresceinIsoThioCyanate & FITC & $420-520$ & 490 & $490-590$ & 520 \\
\hline PropidiumIodide & PI & $450-690$ & 540 & $550-710$ & 610 \\
\hline PhycoErythrin & $\mathrm{PE}$ & $460-590$ & 550 & $550-630$ & 580 \\
\hline AlloPhycoCyanin & APC & $520-670$ & 650 & $640-720$ & 670 \\
\hline
\end{tabular}


were labelled with fluorophores to enable the identification and enumeration using flow cytometry. Table 3 provides excitation and emission specifications of commonly used fluorophores. Besides fluorescent antibodies, specific cell components, such as DNA, can also be labelled with probes that penetrate living or fixed cells (Table 3).

\section{IMMUNOFLUORESCENT SPECIES IDENTIFICATION}

In recent years the number of antibodies against marine eukaryotic phytoplankton species has increased considerably. To date there are antibodies against 28 species in 8 phytoplankton classes (Table 1). Some of the antibodies are directed against species which are microscopically difficult to identify such as small pelagophytes and prasinophytes. Several dinoflagellate species are able to produce potent neurotoxins (Hallegraeff, 1993) and this feature has intensified research in this class: as a result antibodies have been raised against 14 species (Table 1). The raphidophytes Chattonella antiqua and $C$. marina are potentially toxic as well and mo noclonal antibodies have been developed against both species (Hiroishi et al., 1988). The genus Pseudo-nitzschia once contained the non-toxic P. pungens f. pungens and the toxic $P$. pungens f. multiseries. The two forms could not be discriminated with the light microscope and only with electron microscopy accurate taxonomic classification was possible. At present the two Pseudo-nitzschia forms are considered two species (Tomas, 1996), and they can be differentiated with the fluorescence microscope using polyclonal antibodies (Bates et al., 1993).

Most widely used in immunological species identification are polyclonal antibodies. Of a total of 36 antibodies, 26 are polyclonal and only 10 are monoclonal (Table 1). Two polyclonals have been made against Alexandrium minutum, Emiliania huxleyi and Prorocentrum micans. Against Alexandrium tamarense, one polyclonal and several monoclonal antibodies, and for Gymnodinium mikimotoi, considered to be conspecific to Gyrodinium aureolum and Gymnodinium nagasakiense (Gentien, 1998), two monoclonal antibodies have been developed.

Newly produced antibodies are first checked using laboratory cultures before using them in field samples. Some of the antibodies, however, have not yet been applied to field samples (Table 1). Whether applied in cultures or in field samples, the majority of research has been carried out using epifluores- cence microscopy. Flow cytometry has been performed with commercial flow cytometers (Coulter Counter, Becton Dickinson) and with dedicated flow cytometers such as the OPA and EurOPA (Table 1). The application of flow cytometry in combination with immunofluorescence will be described in more detail in the next section.

\section{QUANTITATIVE IMMUNO FLOW CYTOMETRY}

One of the prime objectives of immunochemical labelling is the fast counting of target cells in field samples. The most widely applied method to concentrate, to label and to visualise phytoplankton cells is using membrane filters and epifluorescence microscopy (Table 1). One of the advantages of membrane filtration is that the chance that cells will be lost in the various incubation steps necessary for immunochemical labelling is limited. On the other hand, immunochemical labelling for flow cytometry is performed in tubes in which the cells are repeatedly centrifuged and resuspended before they can be analysed. Furthermore, a flow cytometer is more expensive than an epifluorescence microscope and this is the reason why the combination of immunolabelling and flow cytometry has been tested in a few studies only (Table 1). However, when immuno flow cytometry is feasible, counting can be fast and flow cytometric applications, e.g. size measurements and cell sorting, can be performed with the same speed. Here, examples and quantitative aspects of immuno flow cytometry will be presented.

To our knowledge, the first flow cytometric analysis of immunolabelled eukaryotic marine phytoplankton species was performed on P. micans and G. mikimotoi with the Optical Plankton Analyser or OPA (Vrieling et al., 1993a). A species-specific and a non-specific polyclonal rabbit IgG antibody lead to small (P. micans) and somewhat larger (G. mikimotoi) increases in green fluorescence using a FITC-conjugated goat-anti-rabbit IgG antibody (GAR-FITC). Subsequently, labelling intensity was enhanced using a biotin-streptavidin system (Vrieling et al., 1993b; Fig. 1). To the primary polyclonal rabbit antibody a secondary donkey-anti-rabbit IgGbiotin (DAR-biotin) was bound. The biotinylated secondary antibody was bound with streptavidinFITC, leading to a doubling of green fluorescence intensity as measured with the OPA in comparison with the indirect method (Vrieling et al., 1993b). 
The OPA flow cytometer was also used in measurements of G. mikimotoi testing several monoclonal antibodies prepared against this species (Vrieling et al., 1994). Such measurements were performed in samples of cultures, artificially mixed algal populations as well as in field samples (Vrieling et al., 1994, 1995a, 1996a). In two year old, Lugol-fixed field samples G. mikimotoi could still be counted at concentrations of less than 2000 cells litre $^{-1}$ using a direct monoclonal-FITC label. Although such a direct labelling reduces the number of wash steps in the assay, the recovery of G. mikimotoi cells was low (0-20\%) as compared to light microscopic counts (Vrieling et al., 1995a). On the other hand, when properly, paraformaldehyde-fixed G. mikimotoi cells in mixed algal populations were labelled directly, and measured with the OPA gated on FBG and FBO, the recovery increased to $77 \%$ (Vrieling et al., 1996a).

A special phytoplankton flow cytometer like the OPA is not a prerequisite for measuring potentially toxic, single-celled dinoflagellates, which all are smaller than $100 \mu \mathrm{m}$. Therefore, commercially available flow cytometers have been used successfully too in immunochemical labelling experiments. The thecate genus Alexandrium has received considerable attention, probably because of its potentially toxic effects on a wide variety of animals, including humans (Hallegraeff, 1993). Taylor and Lewis (1995) measured A. tamarense cells labelled with a polyclonal antibody probed with a FITC-conjugated donkey anti-rabbit antibody. Sako et al. (1996) produced monoclonal antibodies against Japanese isolates of Alexandrium catenella and A. tamarense. Labelling took place with goat anti-mouse IgGFITC or indirect with biotinylated goat anti-mouse IgG and streptavidin-FITC in order to enhance label intensity. Fixation of cultures with $2 \%$ formaldehyde produced the strongest fluorescence intensities, and the highest cell recovery $(70 \%)$ in flow cytometric enumeration compared to direct microscope counts. This study by Sako et al. (1996) is the first attempt to measure Alexandrium spp. in field samples using flow cytometry. However, the quantification of Alexandrium spp. was problematic, probably as a results of cell loss during plankton collection and interference from electric noise during analysis (Sako et al., 1996).

A special combination of immunological labelling, using either a fluorophore or magnetic beads, was performed by Costas and Lopez-Rodas (1996). The polyclonal antibody had been produced against Alexandrium minutum but it was genus (Alexandrium) specific (Mendoza et al., 1995). The antibody was first made A. minutum specific by preincubating it with Alexandrium excavatum and Alexandrium affine cells. Field samples (fixed with $4 \%$ buffered formaldehyde) were then treated with the pre-incubated polyclonal in an indirect assay. The secondary antibody was either FITC-conjugated goat anti-rabbit or magnetic beads-conjugated goat anti-rabbit antibody (Costas and Lopez-Rodas, 1996). The FITC-labelled cells were counted with a flow cytometer while bead-labelled cells were isolated using a magnet. The recovery of the FITClabelled A. minutum cells in undiluted seawater samples was quite high (75-99\%), while the beadlabelled cells were also efficiently separated with recoveries ranging from $61-92 \%$ (Costas and LopezRodas, 1996).

\section{Difficulties in quantitative immunological flow cytometry}

There are two major problems in quantifying immunologically labelled cells in flow cytometry. Firstly, the fixation and labelling procedure involves numerous steps (incubation, washing, centrifugation) that can lead to cell loss. Secondly, the label intensity should be at such a level that the target cells produce a signal that is specific and strong enough for them to be discriminated against non-target cells. Since these problems co-occur in immuno flow cytometry, they need serious attention; they will be discussed in more detail.

\section{Fixation and labelling procedure}

Antibodies are produced in animals or in immortal cell lines at a salinity typically 5 times lower than seawater. The phytoplankton cells have to be transferred to this lower salinity before antibodies can be applied. In order to prevent cell disruption due to osmosis the cells have to be fixed, but ironically fixation also leads to some cell loss. The fixation problem is not new, nor can it be avoided. It is necessary, therefore, to quantify and minimalise the artefacts of fixation, and to compare flow cytometric counts with conventional microscopic counts. But first, an appropriate fixation method must be chosen.

One of the most widely used fixatives in quantitative phytoplankton studies is Lugol, an acid iodine solution. Although the monoclonal anti-G. mikimotoi antibody GA8 still recognised Lugol-fixed cells, 
the recovery of the immunological counts were low (Vrieling et al. 1995a) and, therefore, Lugol is not preferable in quantitative studies.

Aldehyde fixatives cross-link proteins, they are colourless and they are routinely used in immunology. Glutaraldehyde is commonly used as a fixative in electron microscopy, but it increases green autofluorescence of phytoplankton cells (Shapiro et al., 1989) and it can reduce antigen binding (Vrieling et al., 1994). Furthermore, glutaraldehyde may lead to false positives, because it can bind IgG to its free active sites (Vrieling and Anderson, 1996). Formaldehyde or 'paraformaldehyde' (= formaldehyde made from freshly depolymerised paraformaldehyde) at 2-4 \% $(w / v)$ concentrations usually lead to good antigen binding capacity. The reason probably is, that the phytoplankton cells that are used to immunise the host animal usually are fixed in the same way. Flow cytometric cell recoveries with formaldehyde fixatives range from 70-99\% (Costas and Lopez-Rodas, 1996; Sako et al., 1996, Vrieling et al., 1996a). Low concentrations (0.01-0.1\%) of paraformaldehyde may be sufficient for intracellular antibody assays (Navaluna et al., 1989); additional permeabilisation of the cell wall using ethanol (Orellana and Perry, 1995) may be necessary. In practice the best fixative, and its optimum concentration, have to be tested experimentally for each species (e.g. Lin and Carpenter, 1996a).

The number of incubation, washing and centrifugation steps will depend on the type of immuno-assay employed (Fig. 1). The optimum protocol, which minimises cell loss and maximises label intensity, must be determined experimentally as well. For instance, the necessary antibody concentration can be measured in a dilution series of the target cells (Orellana and Perry, 1995; Vrieling et al., 1997).

\section{Label intensity}

The emission wavelength of the fluorophore and its intensity, should be such that the target cells are readily identified and counted. In flow cytometry this means, that the label should be excitable with commonly used lasers (e.g. the Argon laser, Table 2), that quantum yield should be high, and the emitted light should have a narrow emission spectrum. In both immuno flow cytometry and epifluorescence microscopy, FluoresceinIsoThioCyanate (FITC) is used almost exclusively as fluorophore (Table 1). Much immunochemical research has been carried out using FITC as a label, and FITC can be excited over a wide range of wavelengths including the $488 \mathrm{~nm}$ line of argon lasers (Table 2,3). The problem of FITC is that it emits at the same wavelengths as the autofluorescent phytoplankton cell wall (Table 3). Phycoerythrin has an excitation maximum at $460 \mathrm{~nm}$ and can also be excited with an Argon laser (Table 3). Phycoerythrin has been used in epifluorescence dual (FITC and PE) staining techniques (Lin and Carpenter, 1996a) but not in flow cytometric applications. AlloPhycoCyanin (APC) is a red fluorescent fluorophore (Table 3) that needs exciting at $630 \mathrm{~nm}$ which means the need for a HeNe laser (Table 2), and bleaching of the chlorophyll's. APC has been used in indirect immunofluorescent techniques, in which $P$. multiseries was counted flow cytometrically (Table I) or in which G. mikimotoi DNA was simultaneously stained with propidium iodide (Fig. 3).
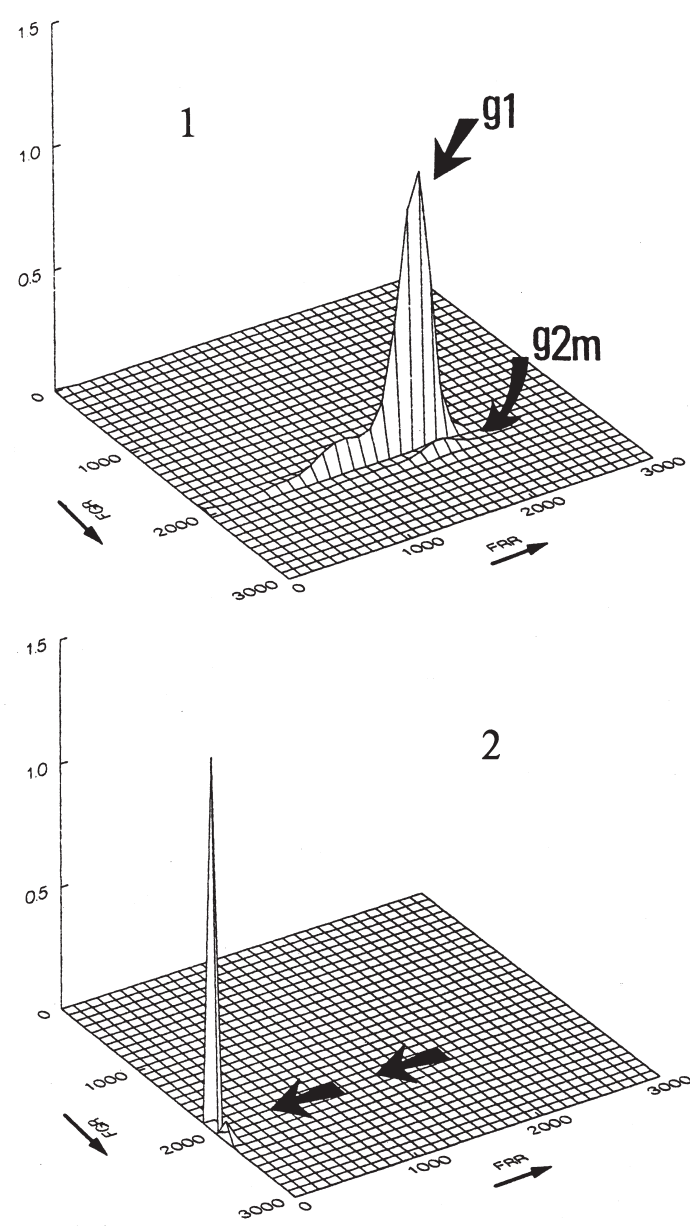

FIG. 3. - Nuclear DNA concentration measurements in species-specific labelled Gymnodinium mikimotoi cells. Three dimensional histogram of AlloPhycoCyanin (FRR: Fluorescence Red $\rightarrow$ Red) species-specific, and propidium iodide (FGR: Fluorescence Green $\rightarrow$ Red) nuclear DNA labelled cells (1), and the control without species-specific label (2). Cells in G1 have $100 \%$ DNA, and cells in the G2M-phase of the cell-cycle, which are going to divide, have a $200 \%$ DNA content. The measurements were made with the EurOPA flow cytometer (L. Peperzak and B. Sandee, unpublished). See Table 2 for excitation and emission wavelengths. 
A new type of secondary antibody labels are the so-called Alexa ${ }^{\mathrm{TM}}$-conjugates. According to the manufacturer, Molecular Probes, these conjugates produce a brighter fluorescence than conventional fluorophores. Additionally, so-called tandem-dyes (Alexa 488 - APC) are available. When such a tandem-dye is excited at $488 \mathrm{~nm}$, it emits at $660 \mathrm{~nm}$. This means that dual-labelled cells (e.g. with FITC and Alexa 488-APC) can be excited with only one laser. However, at present these new labels have not been tested in immuno flow cytometry.

Quantum dots, or semiconductor nanocrystals offer a new class of fluorophores. These are nanometer-sized semi-conductor particles with a broad excitation range and a narrow emission range that is dependent on the particle size (Chan and Nie, 1998; Bruchez et al., 1998). One wavelength can therefore be used to excite many differently sized quantum dots, yielding many emission wavelengths simultaneously. Furthermore, the emission spectra are very narrow, the emission intensity is very high and, important in epifluorescence microscopy, the quantum dots appear to be much more stable against photobleaching (Chan and Nie, 1998; Bruchez et al., 1998). In this case, however, quantum dots are so new that they are not yet available commercially.

\section{QUALITATIVE IMMUNO FLOW CYTOMETRY}

In the previous section the emphasis lay on quantitative species recognition and quantification. The counting of phytoplankton species in a sample of water is one of the first steps in the study of aquatic ecosystems. The measurement of qualitative aspects, such as size and composition of individual cells or populations, is a logical second step. Such measurements can, in principle, be made with a flow cytometer. Measurements of size can be made with any flow cytometer, e.g. as scatter or as time of flight. The composition of the cells can be analysed flow cytometrically only when the desired components are specifically stained. With regard to immunofluorescence, three combinations are possible:

(i) immunofluorescent species identification + non-immunological fluorophore,

(ii) immunofluorescent species identification + immunofluorescent fluorophore,

(iii) non-immunological species identification + immunofluorescent fluorophore.

The fourth combination, in which both fluorophores are non-immunological, are outside the scope of this paper. Of each of the three above mentioned combinations examples will be provided. Unfortunately, the number of practical applications is still limited. Therefore, some of the applications are still theoretical, but they are given to illustrate the potential of flow cytometry in combination with immunofluorescence. As with quantitative flow cytometry, good care has to be taken in cell fixation. When cell components are labelled with an immunological fluorophore, the cells need to be permeabilised so that the antibody can pass the plasmalemma. With respect to this problem Orellana and Perry (1995) and Lin and Carpenter (1996a) found $96 \%$ ethanol to be a good fixative. However, the effect of this method of fixation on cell surface, species-specific, antigens has not been tested yet.

\section{Immunofluorescent species identification + non-immunological fluorophore}

When it is possible to identify a phytoplankton species in a mixed assemblage, additional measurements on its cell-composition can provide worthwhile ecological information. The simplest example is the simultaneous measurement of the cells autofluorescence. The red fluorescence intensity is related to the cellular chlorophyll- $a$ content. For instance, the red chlorophyll- $a$ autofluorescence of immunochemically (FITC)-labelled G. mikimotoi cells has been used in cluster analysis (Vrieling et $a l .$, 1994). In living phytoplankton, chlorophyll-a fluorescence is not a simple measure of chlorophyll$a$, because the fluorescence yield is not constant but depends on the cells irradiance history and physiological status (Kiefer, 1973; Slovacek and Hannan, 1977). For immunological purposes, the cells will be fixed and that may stabilise the fluorescence yield. Unfortunately, Navaluna et al. (1989) found that the red chlorophyll fluorescence of $0.01 \%$ paraformaldehyde fixed cells declines rapidly and significantly in the first 100 hours after fixation. At the moment it is unclear how the immunofluorescence protocol, which also includes several labelling and wash steps, will impair reliable chlorophyll-a measurements.

A second example of immunofluorescent labelling in combination with a non-immunological fluorophore, stems from the flow cytometric measurement of in situ growth rates. Phytoplankton growth rates in the sea can be calculated from temporal, daily or weekly, changes in cell concentra- 
tions. The problems in this approach are that net changes and net growth rates (not intrinsic rates) are calculated, and that the body of water at the sampling location will change in time. The in situ production rate measurements where samples are incubated in bottles, can lead to errors due to the socalled "bottle enclosure effect" (Gieskes et al., 1979). These problems are overcome, when the population of a given species is sampled repeatedly in the same body of water, and if the proportion of the cells that undergo phased cell division in a diel cycle can be measured. Before cell division can take place the DNA in the nucleus must have doubled and, at least in dinoflagellates, this process can be quantified relatively easy. This is the basis of the in situ diel DNA synthesis growth rate determination as described and tested by Carpenter and Chang (1988) and Chang and Carpenter (1988). Because this growth rate determination is based on the proportion of the cells that divide, the method does not require exact quantification of cells. However, a major problem in the original method was the large number of manual microscope DNA measurements that had to be made: 320 cells in 13 samples (Chang and Carpenter, 1988). Flow cytometric DNA measurements, after SYTOX, Pico Green or propidium iodide staining, are made much more rapidly (Veldhuis et al., 1997), and the results can readily be applied to the Carpenter-Chang model (Pan and Cembella, 1998; Peperzak et al., 1998b).

In mixed phytoplankton populations the first step is to identify the target cells. This can be achieved on the basis of cell or nucleus size, e.g. the large nucleus of Prorocentrum micans makes this dinoflagellate distinguishable from accompanying species by propidium iodide staining only (Peperzak and Sandee, unpublished). Small species with body scales such as Emiliania huxleyi, can be identified by their scatter characteristics (Van Bleijswijck and Veldhuis, 1995). A combination of cell specific immunofluorescence and propidium iodide DNA staining is shown in Figure 3. Here, G. mikimotoi cells were labelled with a primary monoclonal, cell wall targeted antibody and a secondary antimouse antibody, conjugated with AlloPhycoCyanin. The red APC-fluorescence, together with the orange propidium iodide fluorescence of the cell nuclei enabled rapid selection of the G. mikimotoi cluster.

The third example that is presented in this section, is based on observations that were made with species-specific cell surface antibodies, and with

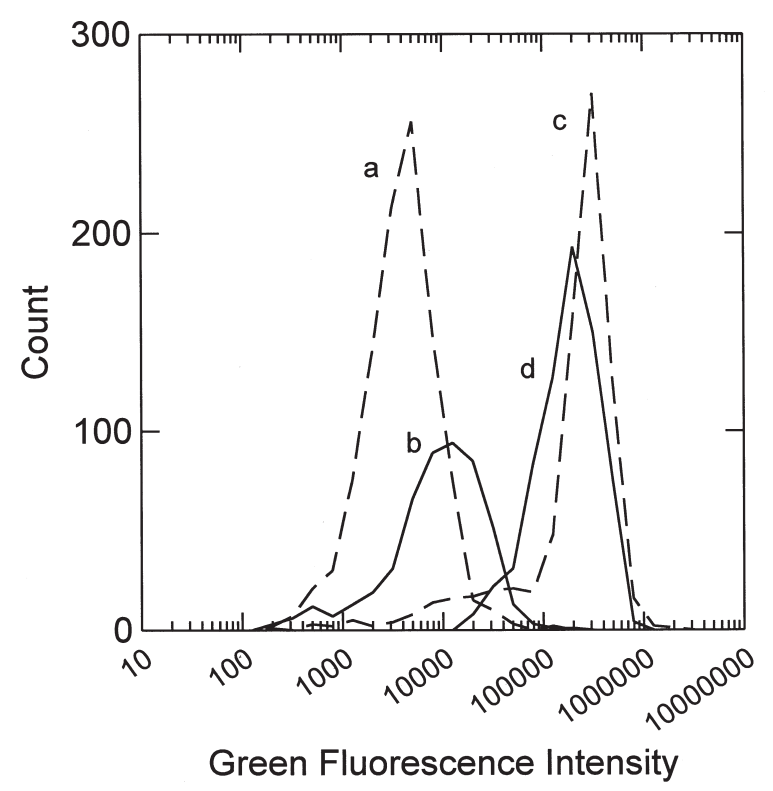

FIG. 4. - Fluorescein labelled Gymnodinium mikimotoi cells. a + b were labelled using universal rRNA-fluorescein probes, $\mathrm{c}+\mathrm{d}$ were labelled using a monoclonal FITC-conjugated antibody. $\mathrm{a}+\mathrm{c}$ were nitrogen stressed (dashed lines), $\mathrm{b}+\mathrm{d}$ were nitrogen replete cells (continuous lines). The rRNA-fluorescein labelled cells have a fluorescence intensity over a decade lower than the monoclonal-FITC labelled cells. Furthermore, rRNA-fluorescein intensity decreases ca. $50 \%$ in the nitrogen-stressed cells (peak a). Measurements were made with the EurOPA flow cytometer as FBG (Fluorescence Blue $\rightarrow$ Green). Peak height of sample b is low due to a lower cell concentration than a, c and d (L. Peperzak and B. Sandee, unpublished).

species-specific ribosomal-RNA probes (e.g. Jonker et al., 2000). Because antibodies are directed against cell surface proteins, an effect of environmental change such as nitrogen limitation, might lead to a reduction in epitopes and, in consequence, a reduction in fluorescence intensity. Fortunately, it has been shown that nutrient limitation does not change the label intensities of $G$. aureolum, G. nagasakiense, A. fundyense and $A$. tamarense (Vrieling et al., 1997; Scholin and Anderson, 1998; Anderson et al., 1999). However, the rRNA label intensity decreases considerably during nitrogen limitation (Scholin and Anderson, 1998; Anderson et al., 1999). In Figure 4 the fluorescence intensities of cells from nitrogen replete and nitrogen stressed G. mikimotoi cultures labelled with either a monoclonal antibody, or a universal rRNA probe are shown. The rRNA fluorescence decreased significantly under nitrogen stress while the antibody fluorescence remained practically unchanged. Combining the antibody with the rRNA labelling methods can therefore be used to measure the physiological state of individual phytoplankton cells in situ. 


\section{Immunofluorescent species identification + immunofluorescent fluorophore}

Once a suitable immunological probe has been found to identify phytoplankton cells flow cytometrically, there are, in principal, no objections to proceed with the immunochemical labelling of certain cell components. As with rRNA labelling, the labelling of cell components can provide physiological information on a per cell basis. A variety of monoclonal and polyclonal antibodies has been produced and applied in whole cell analysis (Table 4). In most studies microscopical techniques have been used, but there are a few culture studies that have employed a flow cytometer. Buma et al. (1995) measured DNA damage from UV radiation in the diatom Cyclotella sp. The $\mathrm{CO}_{2}$-fixing enzyme Rubisco was measured flow cytometrically by Orellana and Perry (1992, 1995) in the diatom Thalassiosira weisflogii and in the prymnesiophyte Isochrysis galbana. To date there are no studies in which the species and a cell component are measured simultaneously with immunological probes (cf. Jochem, 2000).
Before such combined measurements can be made it is necessary that cell surface antigenicity, or species labelling, is not reduced too much by the protocols that are used to fix and permeabilise the cells. The antigenicity of the physiological indicator, e.g. Rubisco, can also be affected by the fixation and permeabilisation treatments (Orellana and Perry, 1995). Because the cell wall has been permeabilised to allow entry of the immunological probe, care must be taken that after labelling the probe-indicator complex does not leak out of the cells. This implies that much work has to be performed to develop reliable immunological combination assays.

As becomes clear from the data in Table 1, much effort in immunological species identification has been directed towards toxic phytoplankton. Phytoplankton cells from this group, however, are not always toxic and the toxin concentration is variable. Ecophysiological knowledge is to be gained, if the effect of the variables that determine toxicity can be measured per cell in culture experiments, as well as in field studies.

Normally, toxicity is measured in samples composed of many cells with a known cell concentra-

TABLE 4. - Whole cell physiological measurements with immunotechniques.

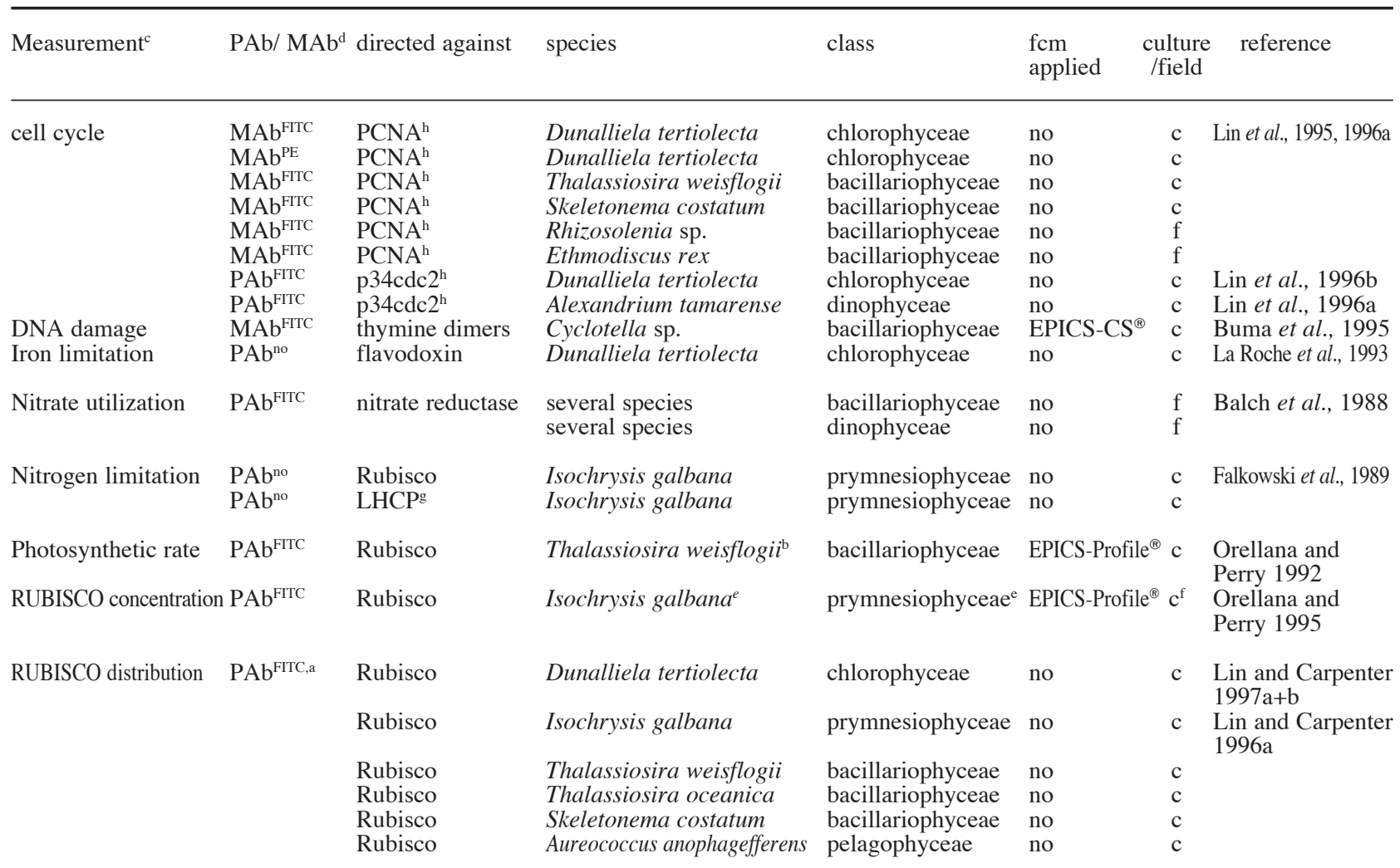

aAb source $=$ Falkowski et al., 1989 cfor whole cells after permeabilisation ebest fixative was $96 \% \mathrm{EtOH}$

g light harvesting $\mathrm{Chl} \mathrm{a/} \mathrm{c} /$ fucoxanthin complex
${ }^{\mathrm{b}}$ probe reacted positively with 38 species of algae using western immunoblotting

dfluorophore used: FITC = FluoresceinIsoThioCyanate, $\mathrm{PE}=$ PhycoErythrin, no $=$ no fluorescent probe ${ }^{\mathrm{f}}$ microscopical tests on field samples were performed

hProliferating Cell Nuclear Antigen (PCNA) and p34cdc2 kinase are cell cycle proteins 
TABLE 5. - Immunological toxin assays. All plankton species listed belong to the dinoflagellates. The only flow cytometric assay was that of Yentsch (1981), however, no immunochemical was used (note b).

\begin{tabular}{|c|c|c|c|c|}
\hline toxin & species & applied in & $\mathrm{PAb} / \mathrm{MAb}^{\mathrm{h}}$ & reference \\
\hline $\begin{array}{l}\text { brevetoxins } \\
\text { ciguatera toxins }\end{array}$ & $\begin{array}{l}\text { Gymnodinium breve } \\
\text { species epibenthic on macroalgae }\end{array}$ & $\begin{array}{l}\text { cell extract } \\
\text { cell extract }\end{array}$ & $\mathrm{PAb}^{\mathrm{e}}$ & Baden et al., 1988 \\
\hline ciguatoxin + congeners & Gambierdiscus toxicus & fish tissue fluid & $\mathrm{MAb}^{\mathrm{g}}$ & Hokama, 1993 \\
\hline $\begin{array}{l}\text { okadaic acid + analogues } \\
\text { okadaic acid }\end{array}$ & $\begin{array}{l}\text { Dinophysis spp. } \\
\text { Prorocentrum spp. }\end{array}$ & $\begin{array}{l}\text { shellfish } \\
\text { cell thin sections }\end{array}$ & $\begin{array}{l}\mathrm{MAb}^{\mathrm{g}} \\
\mathrm{MAb}^{\mathrm{Au}}\end{array}$ & $\begin{array}{l}\text { Matsuura et al., } 1994 \mathrm{a}+\mathrm{b} \\
\text { Zhou and Fritz, } 1994\end{array}$ \\
\hline $\begin{array}{l}\text { saxitoxin } \\
\text { saxitoxins } \\
\text { saxitoxin }\end{array}$ & $\begin{array}{l}\text { G. tamarensis var. excavata } \\
\text { G. tamarense } \\
\text { Alexandrium fundyense }\end{array}$ & $\begin{array}{l}\text { individual cells }{ }^{\mathrm{c}} \\
\text { cells }^{\mathrm{d}} \\
\text { cells }^{\mathrm{d}}\end{array}$ & $\begin{array}{l}\text { neither }^{\mathrm{b}} \\
\mathrm{PAb}^{\mathrm{FITC}} \\
\mathrm{M}+\mathrm{PAb}^{\mathrm{FITC}, \mathrm{Au}}\end{array}$ & $\begin{array}{l}\text { Yentsch, } 1981 \\
\text { Anderson and Cheng, } 1988 \\
\text { Doucette and Anderson, } 1993\end{array}$ \\
\hline
\end{tabular}

alexandrium tamarense

${ }^{\mathrm{b}}$ saxitoxin was oxidised under alkaline conditions to yield a fluorescent compound

cflow cytometry applied

dfluorescence or electron microscopy applied

${ }^{\text {e}}$ radioimmunoassay

f short review on immunological methods for detecting marine toxins

genzyme-colorimetric detection

${ }^{\mathrm{h}}$ method of detection

tion, and the toxin concentration per cell is averaged. The benefit of a per cell toxin assay was already recognised by Yentsch (1981) who used chemical methods to measure saxitoxin in cultured A. tamarense cells with a flow cytometer. Later, immunological methods were employed against saxitoxins and okadaic acid in thin sections of Alexandrium and Prorocentrum cells (Table 5). Because antibodies can pass permeabilised cell walls, as in whole cell physiological measurements (Table 4), there is no principal objection to employ the same technique in toxin measurements. Both polyclonal and monoclonal antibodies have been prepared against the major phytotoxins
(Table 5), although some of them have not been tested on toxic cells directly but on cell extracts or tissue fluids.

One of the problems in toxin analysis could be the low toxin concentration per cell. Therefore, the maximum toxin concentrations reported, for a number of species from a variety of phycotoxic classes, has been listed in Table 6 . In most species the maximum toxin concentrations are in the fmol $\left(10^{-15}\right.$ mol) cell $^{-1}$ range, and although this is quite low, in comparison the cellular Rubisco concentration is in the amol $\left(10^{-18} \mathrm{~mol}\right)$ range (Falkowski et al., 1989). Rubisco can be measured flow cytometrically (Orellana and Perry, 1992, 1995), and the conclusion

TABLE 6. - Maximum toxin concentrations in cells of various dinoflagellate, raphidophyte and diatom species. For comparison, the Rubisco concentration in the small prymnesiophyte Isochrysis galbana, measured immuno flow cytometrically is listed

\begin{tabular}{|c|c|c|c|}
\hline species & toxin & concentration $\mathrm{fmol}_{\text {cell }}{ }^{-1}$ & reference \\
\hline Alexandrium ostenfeldii & total PSP toxins & 2 & Hansen et al., 1992 \\
\hline Alexandrium tamarense & total PSP toxins & 40 & Boyer et al., 1987 \\
\hline Chattonella antiqua & CaTx I-IV & 6 & Khan et al., 1996a \\
\hline Dinophysis acuminata & DTX-1 & $<1$ & Johansson et al., 1996 \\
\hline Dinophysis acuminata & Okadaic Acid & 29 & Johansson et al., 1996 \\
\hline Dinophysis acuminata & Okadaic Acid & 32 & Cembella, 1989 \\
\hline Dinophysis acuta & DTX-1 & 9 & Johansson et al., 1996 \\
\hline Dinophysis acuta & Okadaic Acid & 17 & Johansson et al., 1996 \\
\hline Dinophysis norvegica & Okadaic Acid & 41 & Cembella, 1989 \\
\hline Fibrocapsa japonica & FjTx I-IV & 5 & Khan et al., 1996b \\
\hline Gymnodinium breve & total brevetoxins & 12 & Roszell et al., 1990 \\
\hline Gymnodinium catenatum & total PSP toxins & 200 & Oshima et al., 1993 \\
\hline Gymnodinium sp. $^{\text {a }}$ & Gymnodimine & 0.6 & Seki et al., 1996; M. Satake, pers.comm. \\
\hline Pseudonitzschia multiseries & Domoic Acid & 38 & Pan et al., 1996 \\
\hline Pseudonitzschia seriata & Domoic Acid & 108 & Lundholm et al., 1994 \\
\hline Isochrysis galbana & RUBISCO & $80-39010^{-3}$ & Falkowski et al., 1989 \\
\hline
\end{tabular}

${ }^{\mathrm{h}}$ Gymnodinium cf. mikimotoi (M. Satake, pers.comm.) 
seems permitted that toxins can be measured too, even in moderately toxic cells. Again, trials to establish the feasibility of such measurements have not been undertaken.

\section{Non-immunological species identification + immunofluorescent fluorophore}

This combination is in fact the same as (ii), but the species identification is now of a non-immunological nature. Examples of such species identification techniques, using a flow cytometer, include recognition of size and structure, and fluorometric labelling with dyes, lectins or RNA probes. Because most of these techniques have been reviewed in previous sections they will only be shortly discussed here.

Large dinoflagellates and small scaly prymnesiophytes can be recognised by scatter and time of flight (Van Bleijswijck and Veldhuis, 1995; Peperzak and Sandee, unpublished). Calcofluor white can be used to stain thecate dinoflagellates when the flow cytometer is equipped with a UV laser (Table 3). In certain cases fluorescent lectins may be employed (Lopez Rodas and Costas, 1997); lectins bind to specific carbohydrates on the cell wall. Lectins are not species-specific, but when a set of lectins is used, species can be specifically identified. A relatively new method in species identification employs fluorescent RNA probes (Miller and Scholin, 1998; Scholin and Anderson, 1998).

If species identification can be achieved flow cytometrically with one of these non-immunological probes, the possibilities of qualitative labelling with a second, (non)-immunological fluorophore as described in (i) and (ii) can be examined.

\section{CONCLUDING REMARKS}

The number of immunological techniques that, in principal, can be applied in flow cytometric phytoplankton research has increased in the last decade. Of these techniques the identification and counting of phytoplankton species, especially toxic ones, has received most attention. The adjustment of epifluorescence microscopy protocols for use in flow cytometry, can rapidly increase the number of species to be counted automatically. New fluorescent probes should increase label intensity and hence detectability of the target cells in mixed populations. Once the flow cytometric identification of a single cell is well established, the measurement of several ecologically relevant physiological variables relating to primary production, nutrient limitation or toxin concentration will be a next feasible goal in this field of research.

\section{ACKNOWLEDGEMENTS}

Kees Peeters (NICMM, The Netherlands) critically read the manuscript. Drs. Chris Scholin and Peter Miller (MBARI, USA) provided the probe for the Antibody-RNA labelling comparison. Jan van de Broeke (NICMM, The Netherlands) made Figure 2. Dr. E. Costas (Universidad Complutense, Spain) and Dr. D.M. Anderson (Woods Hole Oceanographic Institution, U.S.A.) provided (un)-published manuscripts. Dr. M. Satake (Tehoka University, Japan) estimated the gymnodimie concentration in $G$. $c f$. mikimotoi.

\section{REFERENCES}

Ackelson, S.G., R.W. Spinrad, C.M. Yentsch, J. Brown.and W. Korjeff-Bellows. - 1988. Phytoplankton optical properties: flow cytometric examination of dilution-induced effects. Applied Optics 27: 1262-1269.

Adachi, M., S. Sako and Y. Ishida. - 1993. The identification of conspecific dinoflagellates Alexandrium tamarense from Japan and Thailand by monoclonal antibodies. Nippon Suisan Gakkaishi 59: 327-332.

Aguilera, A., S. Gonzalez-Gil, B.A. Keafer and D.M. Anderson. 1996. Immunomagnetic separation of cells of the toxic dinoflagellate Alexandrium fundyense from natural plankton samples. Mar. Ecol. Prog. Ser., 143: 255-269.

Aguilera, A., S. Gonzalez-Gil, B.A. Keafer and D.M. Anderson.1998. Isolation of the toxic marine dinoflagellate Alexandrium fundyense from unpreserved cultures by magnetic affinity cell sorting. In: B. Reguera, J. Blanco, M.L. Fernandez and T. Wyatt (eds.), Harmful Algae, pp. 258-259. Xunta de Galicia and Intergovernmental Oceanographic Commission of UNESCO, Vigo.

Anderson, D.M. and T.P. Cheng. - 1988. Intracellular localization of saxitoxins in the dinoflagellate Gonyaulax tamarensis. J. Phycol. 24: 17-22.

Anderson, D.M., D.M. Kulis and E.M. Cosper. - 1989. Immunofluorescent detection of the brown tide organism, Aureococcus anophagefferens. In: E.M. Cosper, V.M. Bricelj and E.J. Carpenter (eds.), Novel Phytoplankton Blooms, pp. 213-228. Springer Verlag, Berlin.

Anderson, D.M., B.A. Keafer, D.M. Kulis, R.M. Waters and R. Nuzzi. - 1993. An immunofluorescent survey of the brown tide chrysophyte Aureococcus anophagefferens along the northeast coast of the United States. J. Plankton Res. 15: 563-580.

Anderson, D.M. - 1995. Identification of harmful algal species using molecular probes: an emerging perspective. In: P. Lassus, G. Arzul, E. Erard, P. Gentien and C. Marcaillou (eds.), Harmful Marine Algal Blooms, pp. 3-13. Lavoisier, Paris.

Anderson, D.M., D.M. Kulis, B.A. Keafer and E. Berdalet. - 1999 Detection of the toxic dinoflagellate Alexandrium fundyense with oligonucleotide and antibody probes: variability in intensity with physiological condition. J. Phycol. 35: 870-883.

Baden, D.G., T.J. Mende and A.M. Szmant. - 1988. Brevetoxins and binding: sodium channels versus antibodies. In: C.M. Yentsch, F.C. Mague and P.K. Horan (eds.), Immunochemical 
approaches to coastal, estuarine and oceanographic questions, pp. 134-144. Springer-Verlag, Berlin.

Balch, W.M., C.M. Yentsch, B. Reguera and W. Campbell. - 1988. Examining nitrate reduction by phytoplankton with an immunoassay. In: C.M. Yentsch, F.C. Mague and P.K. Horan (eds.), Immunochemical approaches to coastal, estuarine and oceanographic questions, pp. 263-276. Springer-Verlag, Berlin.

Bates, S.S., C. Léger, B.A. Keafer and D.M. Anderson. - 1993. Discrimination between domoic-acid-producing and nontoxic forms of the diatom Pseudonitzschia pungens using immunofluorescence. Mar. Ecol. Prog. Ser., 100: 185-195.

Bernhard, M.B., G. Lomi, G. Riparbelli, M. Saletti and A. Zattera. - 1969. Un metodo immunologico per la caratterizzazione del fitoplancton. Estratto dalle Pubbl.Staz.Zool.Napoli, 37: 64-72.

Blasco, D., L. Berard-Therriault, M. Levasseur and E.G. Vrieling. 1996. Temporal and spatial distribution of the ichthyotoxic dinoflagellate Gyrodinium aureolum Hulburt in the St Lawrence, Canada. J. Plankton Res., 18: 1917-1930.

Boyer, G.L., J.J. Sullivan, R.J. Andersen, P.J. Harrison and F.J.R. Taylor. - 1987. Effects of nutrient limitation on toxin production and composition in the marine dinoflagellate Protogonyaulax tamarensis. Mar. Biol., 96: 123-128.

Bruchez, M., M. Moronne, P. Gin, S. Weiss and A.P. Alivisatos. 1998. Semiconductor nanocrystals as fluorescent biological labels. Science, 281: 2013-2016.

Buma, A.G.J., E.J. van Hannen, L. Roza, M.J.W. Veldhuis and W.W.C. Gieskes. - 1995. Monitoring ultraviolet-b-induced DNA damage in individual diatom cells by immunofluorescent thymine dimer detection. J. Phycol., 31: 314-321.

Campbell, L., E.J. Carpenter and V.I. Iacono. - 1983. Identification and enumeration of marine chroococcoid cyanobacteria by immunofluorescence. Appl. Environ. Microbiol., 46: 553-559.

Campbell, L., L.P. Shapiro and E.M. Haugen. - 1994. Immunochemical characterization of eukaryotic ultraplankton from the Atlantic and Pacific oceans. J. Plankton Res., 16: 35-51.

Carpenter, E.J. and J. Chang. - 1988. Species-specific phytoplankton growth rates via diel DNA synthesis cycles. I. Concept of the method. Mar. Ecol. Prog. Ser., 43: 105-111.

Cembella, A.D. - 1989. Occurrence of okadaic acid, a major shellfish toxin, in natural populations of Dinophysis spp. from the eastern coast of North America. J. Appl. Phycol., 1: 307-310.

Chan, W.C.W. and S. Nie. - 1998. Quantum dot bioconjugates for ultrasensitive nonisotopic detection. Science, 281: 2016-2018.

Chang, J. and E.J. Carpenter. - 1988. Species-specific phytoplankton growth rates via diel DNA synthesis cycles. II. DNA quantification and model verification in the dinoflagellate Heterocapsa triquetra. Mar. Ecol. Prog. Ser., 44: 287-296.

Chang, F.H., I. Garthwaite, D.M. Anderson, N. Towers, R. Stewart and L. MacKenzie. - 1999. Immunofluorescent detection of a PSP-producing dinoflagellate, Alexandrium minutum, from Bay of Plenty, New Zealand. New Zealand J. Mar. Fresh. Res., 33. 533-543.

Costas, E. and V. Lopez Rodas. - 1996. Enumeration and separation of the toxic dinoflagellate Alexandrium minutum from natural samples using immunological procedures with blocking antibodies. J. Exp. Mar. Biol. Ecol., 198: 81-87.

Cucci, T.L. and D. Robins. - 1988. Flow cytometry and immunofluorescence in aquatic sciences. In: C.M. Yentsch, F.C. Mague and P.K. Horan (eds.), Immunochemical approaches to coastal, estuarine and oceanographic questions, pp. 184-193. SpringerVerlag, Berlin.

Cunningham, A and G.A. Buonaccorsi. - 1992. Narrow angle forward light scattering from individual algal cells: implications for size and shape discrimination in flow cytometry. J. Plankton Res., 14: 223-234.

Dahl, A.B. and M. Laake. - 1982. Diversity dynamics of marine bacteria studied by immunofluorescent staining on membrane filters. Appl. Environ. Microbiol., 43: 169-176.

Doucette, G.J. and D.M. Anderson. - 1993. Intracellular distribution of saxitoxin in Alexandrium fundyense. In: T.J Smayda and Y. Shimizu (eds.), Toxic Phytoplankton Blooms in the Sea, pp. 863-868. Elsevier, Amsterdam.

Dubelaar, G.B.J., J.W.M. Visser and M. Donze. - 1987. Anomalous behaviour of forward and perpendicular light scattering of cyanobacterium owing to intracellular gas vacuoles. Cytometry, 8: 539-544.

Dubelaar, G.B.J., A.C. Groenewegen, W. Stokdijk, G.J. van den
Engh and J.W.M. Visser. - 1989. Optical Plankton Analyzer: A flow cytometer for plankton Analysis, II: Specifications. Cytometry, 10: 529-539.

Falkowski, P.G., A. Sukenik and R. Herzig. - 1989. Nitrogen limitation in Isochrysis galbana (Haptophyceae) II. Relative abundance of chloroplast proteins. J. Phycol., 25: 471-478.

Gentien, P. - 1998. Bloom dynamics and ecophysiology of the Gymnodinium mikimotoi species complex. In: D.M. Anderson, A.D. Cembella and G.M. Hallegraeff (eds.), Physiological Ecology of Harmful Algal Blooms, pp. 155-173. Springer-Verlag, Berlin.

Gieskes,W.W.C., G.W. Kraay and M.A. Baars. - 1979. Current ${ }^{14}$ C methods for measuring primary production: gross underestimations in oceanic waters. Neth.J.Sea Res., 13: 58-78.

Hallegraeff, G.M. - 1993. A review of harmful algal blooms and their apparent global increase. Phycologia, 32: 79-99.

Hansen, P.J., A.D. Cembella and Ø. Moestrup. - 1992. The marine dinoflagellate Alexandrium ostenfeldii: paralytic shellfish toxin concentration, composition, and toxicity to a tintinnid ciliate. $J$. Phycol., 28: 597-603.

Hiroishi, S., A. Uchida, K. Nagasaki and Y. Ishida. - 1988. A new method for identification of inter- and intra-species of the red tide algae Chattonella antiqua and Chatonella marina (Raphidophyceae) by means of monoclonal antibodies. J. Phycol., 24: 442-444.

Hofstraat, J.W., M.E.J. de Vreeze, W.J.M. van Zeijl, L. Peperzak, J.C.H. Peeters and H.W. Balfoort. - 1991. Flow cytometric discrimination of phytoplankton size classes by fluorescence emission and excitation properties, J. Fluorescence, 1: 249-265.

Hofstraat, J.W., W.J.M. van Zeijl, M.E.J. de Vreeze, L. Peperzak, J.C.H. Peeters, F. Colijn, and M. Rademaker. - 1994. Phytoplankton monitoring by flow cytometry. J. Plankton Res., 16: 1197-1224.

Hokama, Y. - 1993. Recent methods for detection of seafood toxins: recent immunological methods for ciguatoxin and related polyethers. Food Additives and Contaminants, 10: 71-82.

Jochem, F.J. - 2000. Probing the physiological state of phytoplankton at the single-cell level. Sci. Mar., 64(2): 183-195.

Johansson, N., E. Granéli, T. Yasumoto, P. Carlsson and C. Legrand. - 1996. Toxin production by Dinophysis acuminata and D.acuta cells grown under nutrient sufficient and deficient conditions. In: T. Yasumoto, Y. Oshima and Y. Fukuyo (eds.), Harmful and Toxic Algal Blooms, pp. 277-280. Xunta de Galicia and Intergovernmental Oceanographic Commission of UNESCO, Vigo.

Jonker, R.R., J.T. Meulemans, G.B.J. Dubelaar, F. Wilkins and J. Ringelberg. - 1995. Flow cytometry: a powerful tool in analysis of biomass distributions in phytoplankton.Wat. Sci. Tech., 32: $177-182$.

Jonker, R., R. Groben, G. Tarran, L. Medlin, M. Wilkins, L. Garcia, L. Zabala and L. Boddy. -2000 . Automated identification and characterisation of microbial populations using flow cytometry: The AIMS Project. Sci. Mar., 64(2): 225-234.

Khan, S., O. Arakawa and Y. Onoue. - 1996a. A toxicological study of the marine phytoflagellate, Chattonella antiqua (Raphidophyceae). Phycologia, 35: 239-244.

Khan, S., O. Arakawa and Y. Onoue. - 1996b. Neurotoxin production by a chloromonad Fibrocapsa japonica (Raphidophyceae). J. World Aquacult. Soc., 27: 254-263.

Kiefer, D.A. - 1973. Fluorescence properties of natural phytoplankton populations. Mar. Biol., 22: 263-269.

Krause, G.H. and E. Weis. - 1991. Chlorophyll fluorescence and photosynthesis: the basics. Ann. Rev. Plant Physiology, 42: 313-349.

La Roche, J., R.J. Geider, L.M. Graziano, H. Murray and K. Lewis. - 1993. Induction of specific proteins in eukaryotic algae grown under iron-, phosphorus-, or nitrogen-deficient conditions. $J$. Phycol., 29: 767-777.

Lin, S., J. Chang and E.J. Carpenter. - 1995. Growth characteristics of phytoplankton determined by cell cycle proteins: PCNA immunostaining of Dunaliella tertiolecta (Chlorophyceae). J. Phycol., 31: 388-395.

Lin, S. and E.J. Carpenter. - 1996a. An empirical protocol for whole-cell immunofluorescence of marine phytoplankton. $J$. Phycol., 32: 1083-1094.

Lin, S., E.J. Carpenter and J. Chang. - 1996b. Detection of p34cdc2- and cyclin B-like proteins in Dunaliella tertiolecta (Chlorophyceae). Mar. Biol., 125: 603-610. 
Lin, S. and E.J. Carpenter. - 1997a. Rubisco of Dunaliella tertiolecta is redistributed between the pyrenoid and the stroma as a light/shade response. Mar. Biol., 127: 521-529.

Lin, S. and E.J. Carpenter. - 1997b. Pyrenoid localization of Rubisco in relation to the cell cyle and growth phase of Dunaliella tertiolecta (Chlorophyceae). Phycologia, 36: 24-31.

Lopez Barreiro, T., T.A. Villareal and S.L. Morton. - 1998. Development of an antibody against the Texas brown tide (Audeoumbra lagunensis). In: B. Reguera, J. Blanco, M.L. Fernandez and T. Wyatt (eds.), Harmful Algae, pp. 263-265. Xunta de Galicia and Intergovernmental Oceanographic Commission of UNESCO, Vigo.

Lopez Rodas, V. and E. Costas. - 1997. Characterization of morphospecies and strains of Microcystis (Cyanobacteria) from natural populations and laboratory clones using cell probes (lectins and antibodies). J. Phycol., 33: 446-454.

Lopez Rodas, V., A. Aguilera, S. Gonzales-Gil and E. Costas. 1998. Immunogenetical analysis of Prorocentrum species by antibodies. In: B. Reguera, J. Blanco, M.L. Fernandez and T. Wyatt (eds.), Harmful Algae, pp. 280-282. Xunta de Galicia and Intergovernmental Oceanographic Commission of UNESCO, Vigo.

Lundholm, N., J. Skov, R. Pocklington and Ø. Moestrup. - 1994. Domoic acid, the toxic amino acid responsible for amnesic shellfish poisoning, now in Pseudonitzschia seriata (Bacillariophyceae) in Europe. Phycologia, 33: 475-478.

Matsuura, S., Y. Hamano, H. Kita and Y. Takagaki. - 1994a. An ELISA for okadaic acid and its analogs among the diarrhetic shellfish toxins using mouse monoclonal anti-okadaic acid antibodies which are resistant to organic solvents. Jpn. J. Toxicol. Environ. Health, 40: 365-373.

Matsuura, S., H. Kita and Y. Takagaki. - 1994b. Specificity of mouse monoclonal anti-okadaic acid antibodies to okadaic acid and its analogs among diarrhetic shellfish toxins. Biosci. Biotech. Biochem., 58: 1471-1475.

Mendoza, H., V. Lopez-Rodas, S. Gonzales-Gil, A. Aguilera and E. Costas. - 1995. The use of polyclonal antisera and blocking of antibodies in the identification of marine dinoflagellates: species-specific and clone-specific antisera against Gymnodinium and Alexandrium. J. Exp. Mar. Biol. Ecol., 186: 103-115.

Miller, P. and C.A. Scholin. - 1998. Identification and enumeration of cultured and wild Pseudo-nitzschia (Bacillariophyceae) using species-specific LSU rRNA targeted fluorescent probes and filter based whole cell hybridization. J. Phycol., 34: 371382.

Navaluna, N.A., M.J. Perry and M.C. Talbot. - 1989. The effects of chemical fixation on some optical properties of phytoplankton. J. Plankton Res., 11: 15-24.

Nagasaki, K., A. Uchida and Y. Ishida. - 1991. A monoclonal antibody which recognizes the cell surface of red tide alga Gymnodinium nagasakiense. Nippon Suisan Gakkaishi, 57: 12111214.

Orellana, M.V. and M.J. Perry. - 1992. An immunoprobe to measure Rubisco concentrations and maximal photosynthetic rates of individual phytoplankton cells. Limnol. Oceanogr., 37: 478490.

Orellana, M.V. and M.J. Perry. - 1995. Optimization of an immunofluorescent assay of the internal enzyme ribulose-1,5bisphoshate carboxylase (Rubisco) in single phytoplankton cells. J. Phycol., 31: 785-794.

Oshima, Y., S.I. Blackburn and G.M. Hallegraeff. - 1993. Comparative study on paralytic shellfish toxin profiles of the dinoflagellate Gymnodinium catenatum from three different countries. Mar. Biol., 116: 471-476.

Pan, Y., D.V. Subba Rao, K.H. Mann, W.K.W. Li and W.G. Harrison. - 1996. Effects of silicate limitation on production of domoic acid, a neurotoxin, by the diatom Pseudo-nitzschia multiseries. II. Continuous culture studies. Mar. Ecol. Prog. Ser., 131: 235-243.

Pan, Y. and A.D. Cembella. - 1998. Flow cytometric determination of cell cycles and growth rates of Prorocentrum spp. In: B. Reguera, J. Blanco, M.L. Fernandez and T. Wyatt (eds.), Harmful Algae, pp. 173-176. Xunta de Galicia and Intergovernmental Oceanographic Commission of UNESCO, Vigo.

Peeters, J.C.H., G.B.J. Dubelaar, J. Ringelberg and J.W.M. Visser. - 1989. Optical Plankton Analyzer: A flow cytometer for plankton Analysis, I: Design considerations. Cytometry, 10: 529-539.
Peperzak, L., W.H. van de Poll, R. Koeman, E.G. Vrieling and L.P.M.J. Wetsteyn. - 1998a Monitoring toxic phytoplankton: comparison of immunofluorescence assays with conventional light microscopical techniques. In: B. Reguera, J. Blanco, M.L. Fernandez and T. Wyatt (eds.), Harmful Algae, pp. 260-262. Xunta de Galicia and Intergovernmental Oceanographic Commission of UNESCO, Vigo.

Peperzak, L., B. Sandee, R. Jonker and C. Legrand. - 1998b. Measurement of Prorocentrum micans growth rate by flow cytometric analysis of the diel DNA cycle. In: B. Reguera, J. Blanco, M.L. Fernandez and T. Wyatt (eds.), Harmful Algae, pp. 177-178. Xunta de Galicia and Intergovernmental Oceanographic Commission of UNESCO, Vigo.

Roszell, L.E., L.S. Schulman and D.G. Baden. - 1990. Toxin profiles are dependent on growth stages in cultured Ptychodiscus brevis. In: E. Granéli et al. (eds.), Toxic marine phytoplankton, pp. 403-406. Elsevier, Amsterdam.

Sako, Y., M. Adachi and Y. Ishida. - 1993. Preparation and characterization of monoclonal antibodies to Alexandrium species. In: T.J. Smayda and Y. Shimizu (eds.), Toxic Phytoplankton Blooms in the Sea, pp. 87-93. Elsevier, Amsterdam.

Sako, Y., T. Murakami, M. Adachi, A. Uchida, Y. Ishida, M. Yamaguchi and T. Takeuchi. - 1996. Detection of the toxic dinoflagellate Alexandrium species by flow cytometry using a monoclonal antibody. In: T. Yasumoto, Y. Oshima and Y. Fukuyo (eds.), Harmful and Toxic Algal Blooms, pp. 463-466. IOC-UNESCO, Sendai.

Scholin, C.A. and D.M. Anderson. - 1998. Detection and quantification of HAB species using antibody and DNA probes: progress to date and future research objectives. In: B. Reguera, J. Blanco, M.L. Fernandez and T. Wyatt (eds.), Harmful Algae, pp. 253-257. Xunta de Galicia and Intergovernmental Oceanographic Commission of Xunta de Galicia and Intergovernmental Oceanographic Commission of UNESCO, Vigo.

Seki, T., M. Satake, L. MacKenzie, H.F. Kaspar and T. Yasumoto. - 1996. Gymnodimine a novel toxic imine isolated from the Foveaux Strait oysters and Gymnodinium sp. In: T. Yasumoto, Y. Oshima and Y. Fukuyo (eds.), Harmful and Toxic Algal Blooms, pp. 495-498. IOC-UNESCO, Sendai.

Shapiro, H.M. - 1985. Practical Flow Cytometry. Alan R. Liss, Inc. New York.

Shapiro, L.P., L. Campbell and E.M. Haugen. - 1989. Immunochemical recognition of phytoplankton species. Mar. Ecol. Prog. Ser., 57: 219-224.

Slovacek, R.E. and P.J. Hannan. - 1977. In vivo fluorescence determinations of phytoplankton chlorophyll a. Limnol. Oceanogr., 22: 919-925.

Taylor, J.A. and J. Lewis. - 1995. Immunofluorescence of Alexandrium species from the United Kingdom. In: P. Lassus, G. Arzul, E. Erard, P. Gentien and C. Marcaillou (eds.), Harmful Marine Algal Blooms, pp. 89-94. Lavoisier.

Tomas, C.R. (ed.). - 1996. Identifying marine diatoms and dinoflagellates. Academic Press, London.

van Bleijswijk, J., P. van der Wal, R. Kempers, M. Veldhuis, J.R. Young, G. Muyzer, E. de Vrind-de Jong and P. Westbroek. - 1991. Distribution of two types of Emiliania huxleyi (Prymnesiophyceae) in the northeast Atlantic region as determined by immunofluorescence and coccolith morphology. J. Phycol., 27: 566-570.

van Bleijswijk, J.D.L. and M.J.W. Veldhuis. - 1995. In situ gross growth rates of Emiliania huxleyi in enclosures with different phosphate loadings revealed by diel changes in DNA content. Mar. Ecol. Prog. Ser., 121: 271-277.

Veldhuis, M.J.W., T.L. Cucci and M.E. Sieracki. - 1997. Cellular DNA content of marine phytoplankton using two new flurochromes: Taxonomic and ecological implications. J. Phycol., 33: 527-541.

Vrieling, E.G., W.W.C. Gieskes, F. Colijn, J.W. Hofstraat, L. Peperzak and M. Veenhuis. - 1993a. Immunochemical identification of toxic marine algae: first results with Prorocentrum micans as a model organism. In: T.J Smayda and Y. Shimizu (eds.), Toxic Phytoplankton Blooms in the Sea, pp. 925-931. Elsevier, Amsterdam.

Vrieling, E.G., A. Draaijer, W.J.M. van Zeijl, L. Peperzak, W.W.C. Gieskes and M. Veenhuis. - 1993b. The effect of labeling intensity, estimated by real-time confocal laser scanning microscopy, on flow cytometric appearance and identification of immunochemically labeled marine dinoflagellates. J. Phycol., 29: 180-188. 
Vrieling, E.G., L. Peperzak, W.W.C. Gieskes and M. Veenhuis. 1994. Detection of the ichtyotoxic dinoflagellate Gyrodinium (cf.) aureolum and morphologically related Gymnodinium species using monoclonal antibodies: a specific immunological tool. Mar. Ecol. Prog. Ser., 103: 165-174.

Vrieling, E.G., W.W.C. Gieskes, M. Rademaker, G.H. Vriezekolk, L. Peperzak and M. Veenhuis. - 1995a. Flow cytometric identification of the ichthytoxic dinoflagellate Gyrodinium aureolum in the central North Sea. In: P. Lassus, G. Arzul, E. Erard, P. Gentien and C. Marcaillou (eds.), Harmful Marine Algal Blooms, pp. 743-748. Lavoisier.

Vrieling, E.G., R.P.T. Koeman, K. Nagasaki, Y. Ishida, L. Peperzak, W.W.C. Gieskes and M. Veenhuis. - 1995b. Chattonella and Fibrocapsa (Raphidophyceae): first observations of, potentially harmful, red tide organisms in Dutch coastal waters. Neth. J. Sea Res., 33: 183-191.

Vrieling, E.G. and D.M. Anderson. - 1996. Immunofluorescence in phytoplankton research: applications and potential. J. Phycol., 32: $1-16$.

Vrieling, E.G., G.H. Vriezekolk, W.W.C. Gieskes, M. Veenhuis and W. Harder. - 1996a. Immuno-flow cytometric identification and enumeration of the ichthyotoxic dinoflagellate Gyrodinium aureolum Hulburt in artificially mixed algal populations. J. Plankton Res., 18: 1503-1512.

Vrieling, E.G., R.P.T Koeman, C.A. Scholin, P. Scheerman, L.
Peperzak, M. Veenhuis and W.W.C. Gieskes. - 1996b. Identification of a domoic acid-producing Pseudo-nitzschia species (Bacillariophyceae) in the Dutch Wadden Sea with electron microscopy and molecular probes. Eur. J. Phycol., 31: 333-340.

Vrieling, E.G., W.H. Poll van de, G.H. Vriezekolk and W.W.C Gieskes. - 1997. Immuno-flow cytometric detection of the ichthyotoxic dinoflagellates Gyrodinium aureolum and Gymnodinium nagasakiense: independence of physiological state. $J$. Sea Res., 37: 91-100.

Yentsch, C.S. and C.M. Yentsch. - 1979. Fluorescence spectral signatures: the characterisation of phytoplankton populations by the use of excitation and emission spectra. J. Mar. Res., 37: 471-483.

Yentsch, C.M. - 1981. Flow cytometric analysis of cellular saxitoxin in the dinoflagellate Gonyaulax tamarensis var. excavata. Toxicon, 19: 611-621.

Yentsch, C.M. and P.K. Horan. - 1989. Cytometry in Aquatic Sciences. Special Issue of : Cytometry 10: 497-669.

Yentsch, C.S. and D.A. Phinney. - 1988. Spectral fluorescence: a taxonomic tool for studying the structure of phytoplankton populations. J. Plankton Res., 7: 617-632.

Zhou, J. and L. Fritz. - 1994. Okadaic acid antibody localizes to chloroplasts in the DSP-toxin-producing dinoflagellates Prorocentrum lima and Prorocentrum maculosum. Phycologia, 33: 455-461. 